\title{
Purification, virulence and characterization of an extracellular peptidase produced by Aeromonas salmonicida ssp. masoucida isolated from cultured sea cucumber Apostichopus japonicus
}

\author{
Jia-Long Yang, Wen-Bin Zhan*, Li Zhou, Jing Xing \\ Laboratory of Pathology and Immunology of Aquatic Animals, LMMEC, Ocean University of China, Qingdao 266003, \\ PR China
}

\begin{abstract}
Strain H1, Aeromonas salmonicida ssp. masoucida isolated from an ulcer on the sea cucumber Apostichopus japonicus proved to be virulent toward this holothurian at $12^{\circ} \mathrm{C}$. Extracellular products (ECP) of strain H1 were prepared, and an extracellular peptidase of $42 \mathrm{kDa}$ was purified from the ECP using Sephadex G-100 gel filtration chromatography and diethylaminoethyl Sepharose ion exchange chromatography. Stepwise virulence tests on sea cucumbers indicated that the $42 \mathrm{kDa}$ peptidase was the virulence factor of strain $H 1$, and its $L_{50}$ for these holothurians was $1.12 \mu \mathrm{g} \mathrm{g}^{-1}$. A peptidase activity test using azocasein as a substrate showed that optimum $\mathrm{pH}$ and temperature for the peptidase are 8.0 and $40^{\circ} \mathrm{C}$, respectively; the peptidase was completely inactivated above $70^{\circ} \mathrm{C}$. The peptidase was inhibited strongly by $5 \mathrm{mM}$ phenylmethanesulphonyl fluoride, indicating that the enzyme is a serine peptidase.
\end{abstract}

KEY WORDS: Sea cucumber · Bacterial ulceration disease · Aeromonas salmonicida ssp. masoucida · Extracellular peptidase

Resale or republication not permitted without written consent of the publisher

\section{INTRODUCTION}

In recent times, the sea cucumber Apostichopus japonicus has become a major aquaculture product along the coasts of Shandong and Liaoning provinces in China, where 1 to 2 billion larvae may be produced and up to $90000 \mathrm{t}$ of sea cucumbers (live weight) are harvested annually (Wang et al. 2003). The rapid expansion and intensification of sea cucumber farming has led to the occurrence of various diseases, among which epidemic bacterial ulceration disease (which first appeared in 2004) is the most serious and responsible for great losses. In affected sea cucumbers ranging from 5 to $10 \mathrm{~cm}$ in length, the disease symptoms are wasting, excessive mucus production, gut disgorgement, serious ulceration on the body surface and finally a mortality rate up to $80 \%$ as the ulcers spread and autolysis sets in. In our early research, strain H1 isolated from diseased sea cucumbers and identified as Aeromonas salmonicida ssp. masoucida caused sea cucumber death at a $\mathrm{LD}_{50}$ concentration of $1.8 \times$ $10^{7} \mathrm{CFU}$ per sea cucumber (using the injection challenge test at $16^{\circ} \mathrm{C}_{\text {; }}$ Yang et al. 2007); but this $\mathrm{LD}_{50}$ dose did not completely explain the high mortalities in farming operations. Hence, in this study we re-tested the virulence of strain $\mathrm{H} 1$ at $12{ }^{\circ} \mathrm{C}$, and showed that it is highly lethal toward sea cucumbers at lower temperatures.

Aeromonas salmonicida is an important pathogen of many aquatic animals, including sea urchins (Gilles \& Pearse 1986), Atlantic salmon (Bernoth 1997), eel (Kitao et al. 1984), goldfish (Dror et al. 2006) and carp (Evenberg et al. 1986, Austin \& Austin 1993). Since diseases caused by $A$. salmonicida have caused severe 
losses in grow-out farms, it is essential to identify the main pathogenic mechanism of this bacterium in order to develop efficient strategies for preventing outbreaks of disease. Several potential virulence factors of $A$. salmonicida ssp. salmonicida and A. salmonicida ssp. achromogenes have been reported to date, including the surface A-layer protein (Chu et al. 1991), hemolysins (Hirono \& Aoki 1993), H-lysin (Titball \& Munn 1985) and peptidase (Whitby et al. 1992, Austin \& Austin 1993, Gudmundsdóttir et al. 1995), but there is still no report on the causative agent of the disease caused by A. salmonicida ssp. masoucida. Our previous study showed that extracellular products (ECP) of strain $\mathrm{H} 1$ were lethal to sea cucumbers at a $\mathrm{LD}_{50}$ of $5.24 \mathrm{\mu g} \mathrm{g}^{-1}$; the ECPs were inactivated by treatment at $70^{\circ} \mathrm{C}$ for $30 \mathrm{~min}$, and the optimum temperature was $50^{\circ} \mathrm{C}$ (Yang et al. 2007). Here we show that an extracellular peptidase of $42 \mathrm{kDa}$ purified from the ECP by Sephadex G-100 gel filtration chromatography and diethylaminoethyl (DEAE) Sepharose ion exchange chromatography is the virulence factor of strain $\mathrm{H} 1$.

\section{MATERIALS AND METHODS}

Microorganism and culture conditions. Strain H1 (Aeromonas salmonicida ssp. masoucida) was isolated from a sea cucumber ulcer (Yang et al. 2007); strains $\mathrm{H} 2$ and $\mathrm{H} 3$ were also isolated from sea cucumber ulcers but were non-pathogenic strains to holothurians. All strains were cultured on brain heart infusion agar at a salinity and temperature of 20 and $22^{\circ} \mathrm{C}$, respectively.

Virulence test. Healthy sea cucumbers averaging $6 \mathrm{~cm}$ in length were provided by a sea cucumber farm (Shandong, China), and held at $12^{\circ} \mathrm{C}$ in flow-through seawater. The strains were suspended in sterile phosphate-buffered saline ( $\mathrm{PBS}, 0.01 \mathrm{M} \mathrm{NaH}{ }_{2} \mathrm{PO}_{4} \cdot 2 \mathrm{H}_{2} \mathrm{O}$, $0.01 \mathrm{M} \mathrm{Na}_{2} \mathrm{HPO}_{4} \cdot 2 \mathrm{H}_{2} \mathrm{O}, 0.15 \mathrm{M} \mathrm{NaCl}, \mathrm{pH} \mathrm{7.2)}$ and diluted serially after growing for $24 \mathrm{~h}$ on $\mathrm{BHI}$ agar at $22^{\circ} \mathrm{C}$

Virulence was tested in 2 ways: (1) sea cucumbers were slightly wounded (wound length: $2 \mathrm{~mm}$ ) with a razor blade in suspensions of bacteria diluted in filtered seawater to concentrations of $1 \times 10^{4}, 1 \times 10^{5}, 1 \times$ $10^{6}$ and $1 \times 10^{7} \mathrm{CFU}$; (2) sea cucumbers were injected intramuscularly with $50 \mu \mathrm{l}$ of bacterial suspensions at concentrations of $1 \times 10^{4}, 1 \times 10^{5}, 1 \times 10^{6}$ and $1 \times 10^{7}$ $\mathrm{CFU}$ ind. ${ }^{-1}$. In addition, strains $\mathrm{H} 2$ and $\mathrm{H} 3$ were injected at a concentration of $1 \times 10^{7} \mathrm{CFU}$ ind. ${ }^{-1}$ and acted as controls.

The virulence test lasted $2 \mathrm{wk}$, and mortalities of affected sea cucumbers were recorded daily. Re-isolation and identification of the bacteria from moribund sea cucumbers was conducted with $\mathrm{BHI}$ agar plates.
$\mathrm{LD}_{50}$ was calculated by the Reed-Muench method (Reed \& Muench 1938).

Transmission electron microscopy (TEM) observation. For TEM, a bacterial suspension of $10 \mu \mathrm{l}$ was negatively stained with an equal volume of $1 \%$ phosphotungstic acid (PTA, pH 6.8) and applied to a Parlodion ${ }^{\circledR}$-coated copper grid for $3 \mathrm{~min}$, then dried for 10 min, and viewed with JEOL JEM-1200EX transmission electron microscope (Cheng et al. 2006).

Preparation of extracellular products (ECPs). The ECPs were extracted using the cellophane plate technique modified after Liu (1957). Exponential phase cultures of the strain grown in liquid BHI incubated for $18 \mathrm{~h}$ at $22^{\circ} \mathrm{C}$ were spread on sterile cellophane sheets overlying $\mathrm{BHI}$ plates $\left(24 \mathrm{~h}, 22^{\circ} \mathrm{C}\right)$. The cells were rinsed from the plates with PBS ( $\mathrm{pH} 7.2)$ and removed by centrifugation $\left(8000 \times g, 30 \mathrm{~min}, 4^{\circ} \mathrm{C}\right)$. The supernatant was sterilized by filtration through a $0.22 \mu \mathrm{m}$ filter (Millipore), and then precipitated with $80 \%$ saturated ammonium sulphate; ECP produced from the precipitate were dialysed against PBS ( $\mathrm{pH} 7.2$ ) at $4^{\circ} \mathrm{C}$ for $24 \mathrm{~h}$.

Peptidase purification. Gel filtration chromatography: The ECP were concentrated with stirred ultrafiltration cells (Millipore, cut-off $5 \mathrm{kDa}$ ) and loaded into a Sephadex G-100 gel filtration column. Equilibration and elution were carried out in $50 \mathrm{mM}$ Tris- $\mathrm{HCl}$ buffer ( $\mathrm{pH}$ 8.0). The fractions were collected at a flow rate of $0.5 \mathrm{ml} \mathrm{min}^{-1}$ and the protein concentration was monitored at an absorbance of $280 \mathrm{~nm}$. Virulence $\left(\mathrm{LD}_{50}\right.$ to sea cucumber) and enzyme activity of each peak were measured, and the purity of the protein was determined by sodium dodecyl sulphate polyacrylamide gel electrophoresis (SDS-PAGE).

Enzyme activity was determined by the method of Windle \& Kelleher (1997), with azocasein (Sigma) as substrate. Azocasein was dissolved in Tris-HCl buffer (50 mM, pH 8.0) to a concentration of $5 \mathrm{mg} \mathrm{ml}^{-1}$. A concentrated fraction $(0.5 \mathrm{ml})$ of enzyme was incubated with $0.5 \mathrm{ml}$ azocasein for $20 \mathrm{~min}$ at $37^{\circ} \mathrm{C}$, and the reaction was terminated by adding $3.5 \mathrm{ml}$ of $10 \%(\mathrm{w} / \mathrm{v})$ trichloroacetic acid. After centrifugation $(10000 \times g$, $5 \mathrm{~min})$, the supernatant was removed from the settled protein precipitate. The supernatant was mixed with an equal volume of $\mathrm{NaOH}(0.5 \mathrm{M})$, and measured with a spectrophotometer at a wavelength of $440 \mathrm{~nm}$. Controlled ECP were inactivated completely by heating at $100^{\circ} \mathrm{C}$ for $20 \mathrm{~min}$. One unit of enzyme activity was defined as the amount of the enzyme giving an absorbance change of 0.01 in $1 \mathrm{~min}$ at $440 \mathrm{~nm}$. Enzyme activities of the cultured supernatant and ECP were also measured as a control.

Ion exchange chromatography: Peak S2, which showed high virulence and enzyme activity according to the virulence and enzyme activity assays, was concentrated and fractionated with a DEAE Sepharose 
Column (Amersham) using a technique developed by Nishida et al. (1998). Concentrated S2 was injected into the column after equilibration with buffer $(20 \mathrm{mM}$ Tris- $\mathrm{HCl}, \mathrm{pH} 8.0$ ) at a flow rate of $1 \mathrm{ml} \mathrm{min}^{-1}$. The column was washed with the same equilibration buffer to eliminate unbound proteins. The bound proteins were then eluted using a stepwise procedure with a series of buffers containing $\mathrm{NaCl}$ at consecutive molarities of $0.05,0.1,0.15,0.2$ and $0.4 \mathrm{M}$. The protein concentration of the effluent was monitored continually at $280 \mathrm{~nm}$. Virulence, enzyme activity and protein purity were measured for each peak.

Optimal conditions for peptidase. To determine the optimal $\mathrm{pH}$, solutions from $\mathrm{pH} 3.6$ to 13 were prepared with the following buffers (50 mM) (Alam et al. 2005): sodium acetate ( $\mathrm{pH} 3.0$ to 5.0), potassium phosphate ( $\mathrm{pH} 6$ to 8), Tris-HCl ( $\mathrm{pH} 7.0$ to 9.0), sodium borate (pH 9.0 to 10.0), and glycine- $\mathrm{NaOH}$ (pH 11.0 to 13.0).

To determine optimal temperature profiles, enzyme assays were carried out at 4, 10, 20, 30,40,50,60, 70 and $80^{\circ} \mathrm{C}$ using the method described in 'Peptidase purification'.

Thermal stability of peptidase. To determine the thermal stability of the peptidase, it was pre-incubated for $30 \mathrm{~min}$ at $4,10,20,30,40,50,60,70$ and $80^{\circ} \mathrm{C}$, and activity was measured at $37^{\circ} \mathrm{C}$.

Inhibition of peptidase. To investigate the effects of oxidizing agents, detergents, peptidase inhibitors and metal ions on peptidase activity, enzymatic assays were carried out after pre-incubation for $1 \mathrm{~h}$ with iodoacetic acid, sodium dodecyl sulphate (SDS), phenylmethanesulphonyl fluoride (PMSF), ethylenediamine tetraacetic acid (EDTA), $\mathrm{Ca}^{2+}, \mathrm{Mg}^{2+}, \mathrm{Mn}^{2+}$ and $\mathrm{Hg}^{2+}$, after which enzyme activity was monitored by the method described in 'Peptidase purification'.

\section{RESULTS}

\section{Virulence tests and transmission electron microscopy observations}

Three strains (H1, H2 and H3) were used in the virulence test. Strains H2 and H3 were not able to infect sea cucumber in either challenge method, while strain H1 was highly virulent to holothurians (Table 1). Strain $\mathrm{H} 1$ caused chronic infection at a $\mathrm{LD}_{50}$ of $1.0 \times 10^{5.5} \mathrm{CFU}$ per sea cucumber through immersion challenge, and an acute infection at a concentration of $1.0 \times 10^{5.25} \mathrm{CFU}$ per sea cucumber through injection challenge. The symptoms of moribund sea cucumbers in both challenge styles were similar to those observed in moribund, naturally infected individuals.

Pure cultures of the predominant strain of the bacterium were re-isolated from the ulcers of moribund sea cucumbers after bacterial challenge; these isolates were used to re-infect individuals, and similar symptoms were observed.

Strain H1 was a Gram negative, straight rod bacterium with rounded ends and no flagellum (Fig. 1). The cells were ca. $0.5 \mu \mathrm{m}$ in diameter and $1.2 \mu \mathrm{m}$ in length, and occurred in pairs.

\section{Extracellular peptidase purification and virulence testing}

Gel filtration chromatography was performed on ECP, and 2 peaks, S1 and S2, were collected (Fig. 2). Although the fraction at peak S2 was at a lower concentration than the fraction at peak S1, S2 had high enzyme activity and virulence (Table 2 ). Ion exchange chromatography was performed on the fraction from

Table 1. Aeromonas salmonicida ssp. masoucida, strain H1. Virulence to sea cucumbers. $\mathrm{n}=10$ sea cucumbers in each test group

\begin{tabular}{|lccr|}
\hline Challenge style & $\begin{array}{c}\text { Dose }(\mathrm{CFU} \\
\left.\text { ind }{ }^{-1}\right)\end{array}$ & $\begin{array}{c}\text { No. of } \\
\text { dead sea } \\
\text { cucumbers }\end{array}$ & $\begin{array}{c}\text { Mortality } \\
(\%)\end{array}$ \\
\hline Bath (wounded) & $1 \times 10^{7}$ & 10 & 100 \\
& $1 \times 10^{6}$ & 7 & 70 \\
& $1 \times 10^{5}$ & 3 & 30 \\
& $1 \times 10^{4}$ & 0 & 0 \\
& $1 \times 10^{7}$ & 10 & 100 \\
& $1 \times 10^{6}$ & 8 & 80 \\
$1 \times 10^{5}$ & 4 & 40 \\
& $1 \times 10^{4}$ & 0 & 0 \\
\hline
\end{tabular}

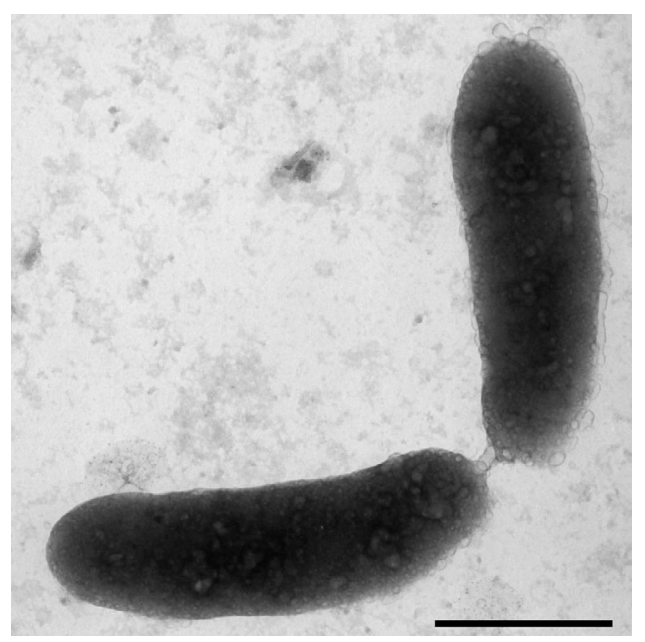

Fig. 1. Aeromonas salmonicida ssp. masoucida. Cell morphology (TEM) showing characteristic pairing $($ bar $=500 \mathrm{~nm})$ 


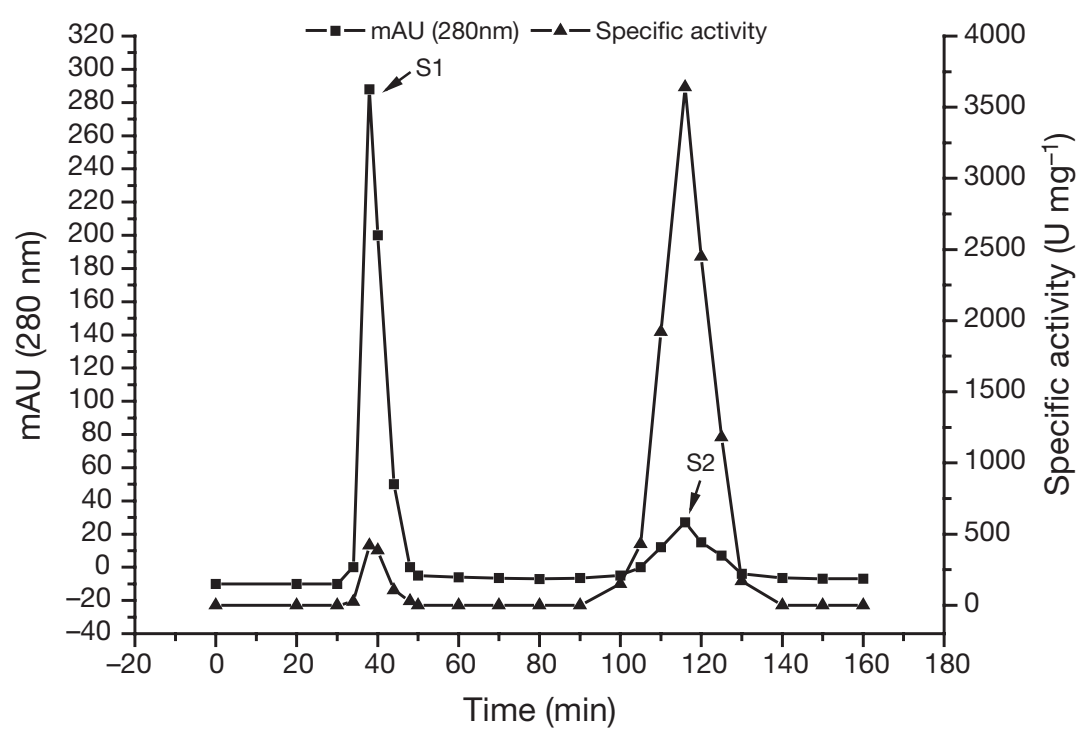

Fig. 2. Aeromonas salmonicida ssp. masoucida. Purification profile of peptidase from extracellular products (gel filtration on a Sephadex G-100 column). The concentrated extracellular products were injected into a $1.5 \mathrm{~cm} \times 70 \mathrm{~cm}$ column, equilibrated and eluted with $50 \mathrm{mM}$ Tris-HCl buffer ( $\mathrm{pH}$ 8.0) at a flow rate of $0.5 \mathrm{ml} \mathrm{min}^{-1}$. Two peaks (S1, S2) were collected, and enzyme activity of each peak measured at $37^{\circ} \mathrm{C}$ and $\mathrm{pH} 8.0$

peak S2 (Fig. 2); peak D1 (among 5 peaks D1, D2, D3, D4 and D5 that separated) (Fig. 3) showed much higher enzyme activity and virulence (Table 2) than fraction S2, and was identified as the virulent factor of strain $\mathrm{H} 1$.

SDS-PAGE of the products at different stages of purification (Fig. 4) showed that the ECP consist of more than 13 protein bands; although the fraction from peak S2 (Fig. 2) had high enzyme activity and virulence, it was not a purified protein; the fraction from peak D1 (Fig. 3) consisted of a single protein band of $42 \mathrm{kDa}$, showing that the peptidase was purified.

The stepwise procedure purified the peptidase 21.9-fold, with a total yield of $1.7 \%$. The enzyme was virulent $\left(\mathrm{LD}_{50}\right)$ to sea cucumbers at $1.12 \mu \mathrm{g} \mathrm{g}^{-1}$ body weight, which is 4.7 -fold higher than the virulence of the ECP (Table 2).

\section{Optimal conditions, thermal stability and inhibition of the peptidase}

Measurements through a broad $\mathrm{pH}$ range revealed that the optimum working $\mathrm{pH}$ for the enzyme was 8.0 (Fig. 5). Enzyme activity was 70 to $80 \%$ of its maximal value at $\mathrm{pH} 5.0$ and 10.0. Enzyme activity declined to a greater extent under acidic conditions than under alkaline conditions. The optimum temperature across the range 4 to $80^{\circ} \mathrm{C}$ was $40^{\circ} \mathrm{C}$ (at pH 8.0) (Fig. 6).

The peptidase was stable for $30 \mathrm{~min}$ when incubated at temperatures below $40^{\circ} \mathrm{C}$, but activity declined strongly in temperature over $40^{\circ} \mathrm{C}$. The enzyme was inactivated at temperatures $>70^{\circ} \mathrm{C}$ (Fig. 6).

Effects of oxidizing agents, detergents, peptidase inhibitors and metal ions on enzyme activity were investigated by measuring residual activity after incubation with each of these potential inhibitors for a fixed length of time. Iodoacetic acid (oxidizing agent) and SDS (detergent) reduced enzyme activity to $58 \%$ and $84 \%$ of maximum, repectively. The enzyme was slightly inhibited by EDTA (inhibitor of metal-peptidase and chelating agent), with a loss of $18 \%$ of the original activity, but PMSF (the serine peptidase inhibitor) reduced enzyme activity by $98 \%$; residual activity of the enzyme after incubation with $\mathrm{Hg}^{2+}$ and $\mathrm{Mn}^{2+}$ were $36 \%$ and $52 \%$ of maximum values, respec-

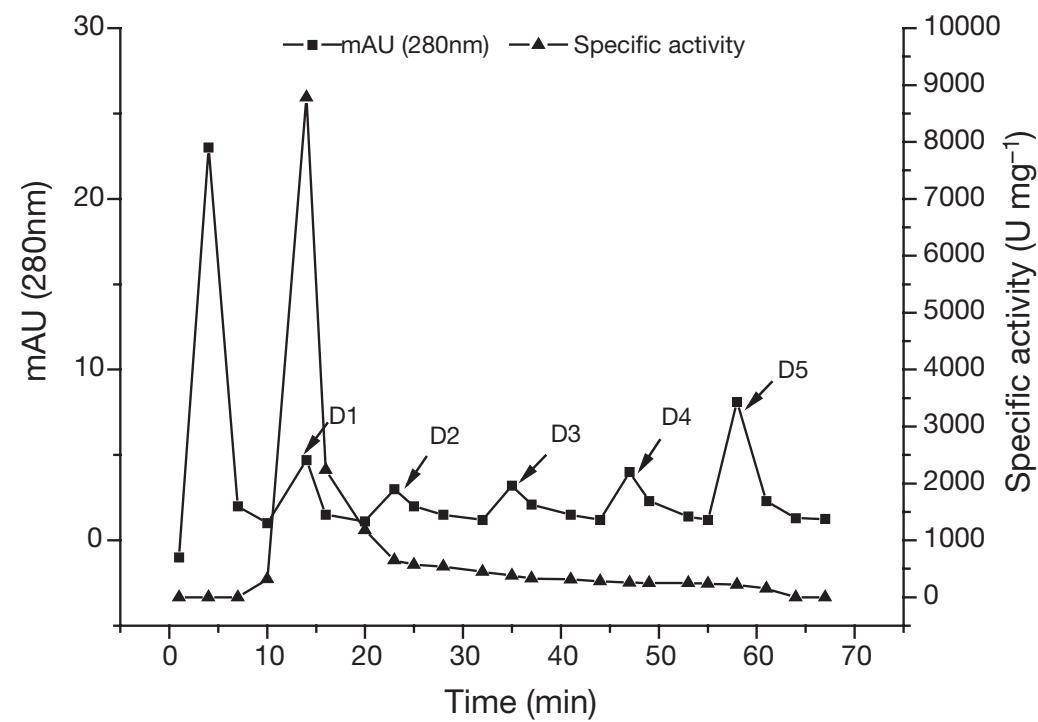

Fig. 3. Aeromonas salmonicida ssp. masoucida. Elution profile of peptidase from peak S2 (Fig. 2) by diethylaminoethyl Sepharose ion exchange chromatography. The concentrated S2 fraction was loaded into the column, which was then washed with $20 \mathrm{mM}$ Tris- $\mathrm{HCl}(\mathrm{pH}$ 8.0) and the bound proteins were eluted stepwise with the same buffer containing $\mathrm{NaCl}$ at $0.05,0.1,0.15,0.2$ and 0.4 M. Five peaks (D1, D2, D3, D4 and D5) were collected, and the enzyme activity of each was measured at $37^{\circ} \mathrm{C}$ and $\mathrm{pH} 8.0$ 
tively. $\mathrm{Ca}^{2+}$ and $\mathrm{Mg}^{2+}$ increased activity by $9 \%$ and $3 \%$, respectively (Table 3 ).

\section{DISCUSSION}

Since first reported by Morgan (2000), bacterial ulceration disease in sea cucumbers has been spreading widely and different pathogens causing severe loss have been isolated. Vibrio harveyi may be the pathogen of affected holothurians off Bribie Island, Australia (Morgan 2000). Vibrio spp., Bacteroides spp., and Alphaproteobacterium were isolated from lesions of sea cucumbers off Madagascar (Becker et al. 2004). In the present and our previous work, we demonstrated that Aeromonas salmonicida ssp. masoucida is

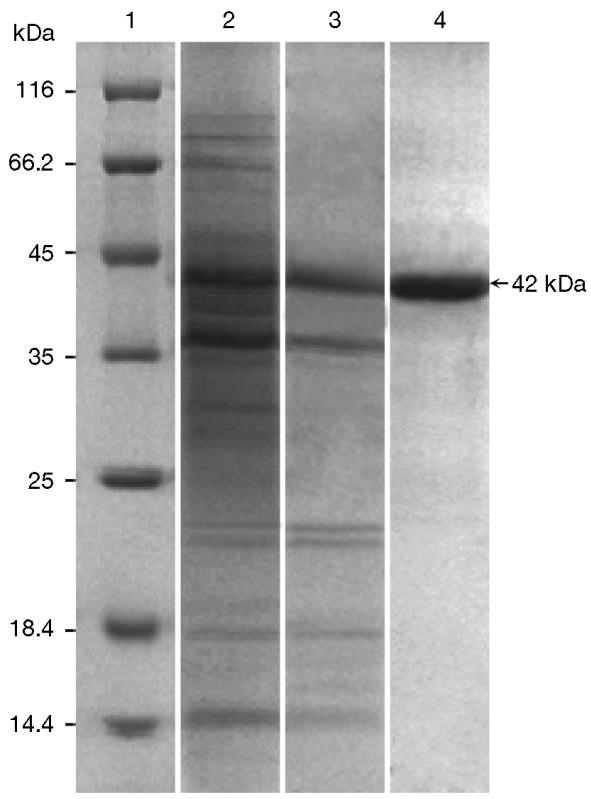

Fig. 4. Aeromonas salmonicida ssp. masoucida. SDS-PAGE of extracellular peptidase at different stages of purification. Lane 1: molecular weight marker; Lane 2: extracellular products; Lane 3: peak S2 from Sephadex G-100 gel filtration chromatography; Lane 4: purified peptidase (peak D1 from DEAE Sepharose ion exchange chromatography) the pathogen of sea cucumber ulceration disease in Shandong province, China; we also showed that strain $\mathrm{H} 1$ was more lethal at low temperatures $\left(12^{\circ} \mathrm{C}\right)$, which might explain why sea cucumber ulceration disease prevails in winter in northern China.

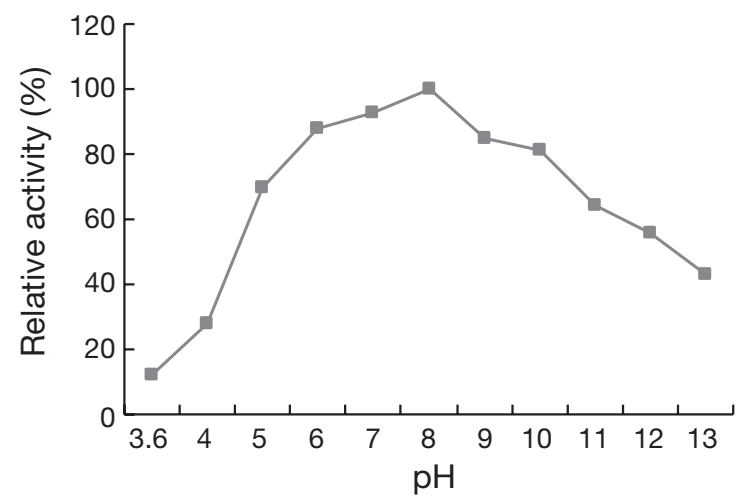

Fig. 5. Aeromonas salmonicida ssp. masoucida. Effects of pH on enzyme activity. Enzyme samples were incubated in respective buffers at $37^{\circ} \mathrm{C}$ and relative activity was calculated. Relative activity is a proportion (\%) of maximum peptidase activity

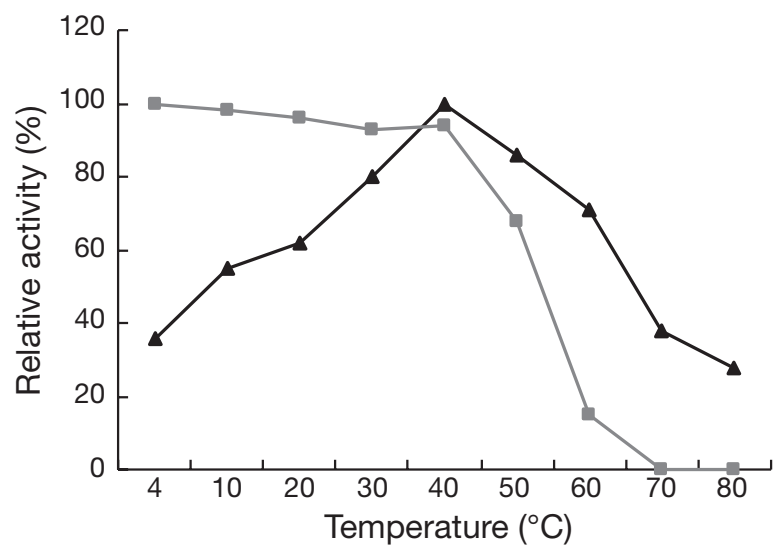

Fig. 6. Aeromonas salmonicida ssp. masoucida. Temperature optimum and thermal stability of the peptidase. - - -: temperature optimum; enzyme activity was measured between 4 and $80^{\circ} \mathrm{C}$ at $\mathrm{pH}$ 8.0. - - -: thermal stability; peptidase was incubated for $30 \mathrm{~min}$ at temperatures shown and relative activity was calculated (proportion (\%) of maximum peptidase activity)

Table 2. Aeromonas salmonicida ssp. masoucida. Purification of extracellular peptidase

\begin{tabular}{|lcccccc|}
\hline Fraction & $\begin{array}{c}\text { Total } \\
\text { protein }(\mathrm{mg})\end{array}$ & $\begin{array}{c}\text { Protein } \\
\text { yield (\%) }\end{array}$ & $\begin{array}{c}\text { Specific } \\
\text { activity } \\
\left(\mathrm{U} \mathrm{mg}^{-1}\right)\end{array}$ & $\begin{array}{c}\text { Purification } \\
(\text { fold: geometric } \\
\text { mean increase) }\end{array}$ & $\begin{array}{c}\text { Virulence }\left(\mathrm{LD}_{50}\right) \\
\left(\mu \mathrm{g} \mathrm{g}^{-1}\right. \\
\text { weight })\end{array}$ & $\begin{array}{c}\text { Purification of virulence } \\
(\text { fold: geometric } \\
\text { mean increase) }\end{array}$ \\
\hline Culture supernatant & 3250 & 100 & 400 & 1 & - & - \\
Extracellular products & 1850 & 57 & 588 & 1.5 & 5.24 & 1 \\
Sephadex G-100 & 370 & 11.4 & 3640 & 9.1 & 2.16 & 2.4 \\
DEAE Sepharose & 56 & 1.7 & 8780 & 21.9 & 1.12 & 4.7 \\
\hline
\end{tabular}


Table 3. Aeromonas salmonicida ssp. masoucida. Effect of various reagent concentrations on peptidase activity. SDS: sodium dodecyl sulphate; PMSF: phenylmethanesulphonyl fluoride; EDTA: ethylenediamine tetraacetic acid

\begin{tabular}{|lcc|}
\hline Reagent & Concentration (mM) & Residual activity (\%) \\
\hline None & 0 & 100 \\
Iodoacetic acid & 10 & 58 \\
EDTA & 5 & 82 \\
PMSF & 5 & 2 \\
SDS & 5 & 84 \\
$\mathrm{Hg}^{2+}$ & 5 & 36 \\
$\mathrm{Mn}^{2+}$ & 5 & 52 \\
$\mathrm{Ca}^{2+}$ & 5 & 109 \\
$\mathrm{Mg}^{2+}$ & 5 & 103 \\
\hline
\end{tabular}

Although our work is the first to show that sea cucumber ulceration disease is caused by Aeromonas salmonicida, there is a report of sea urchin disease caused by A. salmonicida (Gilles \& Pearse 1986). Thus, we have added to the list of hosts for this bacterium.

The fact that ECP of strain H1 contained a peptidase that was lethal to sea cucumbers whereas the inactivated ECP $\left(100^{\circ} \mathrm{C}, 30 \mathrm{~min}\right)$ was not, shows that peptidase activity is an indispensable factor for strain $\mathrm{H} 1$ virulence (Yang et al. 2007). This conclusion was further corroborated by results of the virulence and enzyme activity analyses of different chromatogram peaks, which showed that virulence increased with increasing peptidase activity levels. A serine peptidase with a single band of $42 \mathrm{kDa}$ molecular weight on the SDS-PAGE was purified and is considered to be the virulence factor of Aeromonas salmonicida ssp. masoucida. This is different from the $70 \mathrm{kDa}$ serine peptidase of A. salmonicida ssp. salmonicida (Fyfe et al. 1987, Price et al.1990) and the $20 \mathrm{kDa}$ toxic metallocaseinase of A. salmonicida ssp. achromogenes (Gudmundsdóttir et al. 1995).

The peptidase of strain $\mathrm{H} 1$ was active over broad $\mathrm{pH}$ (6.0 to 10.0$)$ and temperature $\left(30\right.$ to $\left.60^{\circ} \mathrm{C}\right)$ ranges, with maximum activity at $\mathrm{pH} 8.0$ and $40^{\circ} \mathrm{C}$; the enzyme was not thermally stable and was completely inactivated over $70^{\circ} \mathrm{C}$. The enzyme was strongly inhibited in the presence of $5 \mathrm{mM}$ PMSF, a common inhibitor of serine peptidase, but was not very sensitive to other inhibitors, indicating that the peptidase of strain $\mathrm{H} 1$ is a serine peptidase.

The extracellular peptidase of Aeromonas salmonicida is a significant exotoxin that causes serious diseases and disorders in aquatic animals (Fyfe et al. 1987, Price et al. 1990, Gudmundsdóttir et al. 1995). We have shown that a $42 \mathrm{kDa}$ serine extracellular peptidase is the main virulence factor of the A. salmonicida ssp. masoucida.
Acknowledgements. This study was sponsored by the National 863 Project (Grant2006AA100306) and the Fund of Ocean University of China (Grant1400-813764).

\section{LITERATURE CITED}

Alam SI, Smita D, Reddy GSN, Bhattacharya BK, Shivaji S, Singh L (2005) Purification and characterisation of extracellular peptidase produced by Clostridium sp. from Schirmacher oasis, Antarctica. Enzyme Microb Technol 36: 824-831

Austin B, Austin DA (1993) Aeromonadaceae representatives (Aeromonas salmonicida). In: Austin B, Austin DA (eds) Bacterial fish pathogens, 2nd edn. Ellis Horwood, Chichester, p 86-170

Becker P, Gillan D, Lanterbecq D, Jangoux M, Rasolofonirina R, Rakotovao J, Eeckhaut I (2004) The skin ulceration disease in cultivated juveniles of Holothuria scabra (Holothuroidea, Echinodermata). Aquaculture 242:13-30

Bernoth EM (1997) Furunculosis: the history of the disease and of disease research. In: Bernoth EM, Ellis AE, Midtlyng PJ, Olivier G, Smith P (eds) Furunculosis: multidisciplinary fish disease research. Academic Press, London, p 1-20

Cheng SH, Zhan WB, Xing J, Sheng XZ (2006) Development and characterization of monoclonal antibody to the lymphocystis disease virus of Japanese flounder Paralichthys olivaceus isolated from China. J Virol Methods 135:173-180

Chu S, Cavaignac S, Feutrier J, Phipps BM, Kostrzynska M, Kay WW, Trust TJ (1991) Structure of the tetragonal surface virulence array protein and gene of Aeromonas salmonicida. J Biol Chem 266:15258-15265

Dror M, Sinyakov MS, Okun E, Dym M, Sredni B, Avtalion RR (2006) Experimental handling stress as infection-facilitating factor for the goldfish ulcerative disease. Vet Immunol Immunopathol 109:279-287

> Evenberg D, de Graaff P, Fleuren W, van Muiswinkel WB (1986) Blood changes in carp (Cyprinus carpio) induced by ulcerative Aeromonas salmonicida infections. Vet Immunol Immunopathol 12:321-330

Fyfe L, Coleman G, Munro ALS (1987) Identification of major common extracellular proteins secreted by Aeromonas salmonicida strains isolated from diseased fish. Appl Environ Microbiol 53:722-726

Gilles KW, Pearse JS (1986) Disease in sea urchins Strongylocentrotus purpuratus: experimental infection and bacterial virulence. Dis Aquat Org 1:105-114

Gudmundsdóttir S, Magnadóttir B, Gudmundsdóttir BK (1995) Effects of antigens from Aeromonas salmonicida ssp. achromogenes on leukocytes from primed and unprimed Atlantic salmon (Salmo salar L.). Fish Shellfish Immunol 5:493-504

Hirono I, Aoki T (1993) Cloning and characterization of three hemolysin genes from Aeromonas salmonicida. Microb Pathog 15:269-282

Kitao T, Yoshida T, Aoki T, Fukudome M (1984) Atypical Aeromonas salmonicida, the causative agent of an ulcer disease of eel occurred in Kagoshima Prefecture. Fish Pathol 19:113-117

Liu PV (1957) Survey of hemolysin production among species of Aeromonas hydrophila with reduced virulence for fish. Infect Immun 74:718-727

Morgan AD (2000) Aspects of sea cucumber broodstock management (Echinodermata: Holothuroidea). SPC Beche-demer Info Bull 13:2-8 
Nishida H, Enokida T, Hiramatsu N, Hara A, Yoshimizu M (1998) Purification of immunoglobulin M (IgM) in serum of Japanese flounder (Paralichthys olivaceus). Bull Fac Fish Hokkaido Univ 49:157-164

Price NC, Banks RM, Campbell CM, Duncan D, Stevens L (1990) The specificity of the major $(70 \mathrm{kDa})$ peptidase secreted by Aeromonas salmonicida. J Fish Dis 13:49-58

Reed LJ, Muench H (1938) A simple method of estimating fifty percent end-points. Am J Hyg 27:493-497

Titball RW, Munn CB (1985) The purification and some properties of H-lysin from Aeromonas salmonicida. J Gen Microbiol 131:1603-1609

Wang YG, Zhang CY, Rong XJ, Chen JJ, Shi CY (2003) Diseases of cultured sea cucumber (Apostichopus japonicus) in China. In: Lovatelli A, Conand C, Purcell S, Uthicke S,

Editorial responsibility: David Bruno,

Aberdeen, UK
Hamel JF, Mercier A (eds) Advances in sea cucumber aquaculture and management. FAO Fisheries Technical Report No. 463, FAO, Rome, p 297-310

Whitby PW, Landon M, Coleman G (1992) The cloning and nucleotide sequence of the serine protease gene (aspA) of Aeromonas salmonicida ssp. salmonicida. FEMS Microbiol Lett 78:65-71

Windle HJ, Kelleher D (1997) Identification and characterization of a metallopeptidase activity from Helicobacter pylori. Infect Immun 65:3132-3137

Yang JL, Zhou L, Xing J, Sheng XZ, Zhan WB (2007) Identification of Aeromonas salmonicida associated with skin ulceration of cultured sea cucumber Apostichopus japonicus and characterization of the extracellular products. J Fish Sci Sin 14:981-989 (in Chinese with English abstract)

Submitted: January 31, 2008; Accepted: July 17, 2008 Proofs received from author(s): November 27, 2008 